\title{
Potentially bioavailable iron delivery by iceberg-hosted sediments and atmospheric dust to the polar oceans
}

\author{
Robert Raiswell ${ }^{1}$, Jon R. Hawkings ${ }^{2}$, Liane G. Benning ${ }^{1,3}$, Alex R. Baker ${ }^{4}$, Ros Death ${ }^{2}$, Samuel Albani $^{5, a}$, \\ Natalie Mahowald ${ }^{5}$, Michael D. Krom ${ }^{1,6}$, Simon W. Poulton ${ }^{1}$, Jemma Wadham ${ }^{2}$, and Martyn Tranter ${ }^{2}$ \\ ${ }^{1}$ Cohen Biogeochemistry Laboratory, School of Earth and Environment, University of Leeds, Leeds LS2 9JT, UK \\ ${ }^{2}$ Bristol Glaciology Centre, School of Geographical Sciences, University of Bristol, Bristol BS8 1SS, UK \\ ${ }^{3}$ GFZ, German Research Centre for Geosciences, Telegrafenberg, 11473 Potsdam, Germany \\ ${ }^{4}$ Laboratory for Global Marine and Atmospheric Chemistry, School of Environmental Sciences, \\ University of East Anglia, Norwich NR4 7TJ, UK \\ ${ }^{5}$ Department of Earth and Atmospheric Sciences, Cornell University, Ithaca, New York, USA \\ ${ }^{6}$ Department of Marine Biology, Haifa University, Haifa, Israel \\ anow at: the Institute for Geophysics and Meteorology, University of Cologne, Cologne, Germany
}

Correspondence to: Robert Raiswell (r.raiswell@see.leeds.ac.uk)

Received: 20 January 2016 - Published in Biogeosciences Discuss.: 8 February 2016

Revised: 5 June 2016 - Accepted: 17 June 2016 - Published: 6 July 2016

\begin{abstract}
Iceberg-hosted sediments and atmospheric dust transport potentially bioavailable iron to the Arctic and Southern oceans as ferrihydrite. Ferrihydrite is nanoparticulate and more soluble, as well as potentially more bioavailable, than other iron (oxyhydr)oxide minerals (lepidocrocite, goethite, and hematite). A suite of more than 50 iceberghosted sediments contain a mean content of $0.076 \mathrm{wt} \% \mathrm{Fe}$ as ferrihydrite, which produces iceberg-hosted Fe fluxes rang-

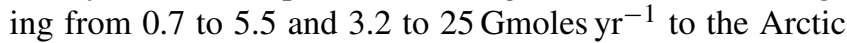
and Southern oceans respectively. Atmospheric dust (with little or no combustion products) contains a mean ferrihydrite $\mathrm{Fe}$ content of $0.038 \mathrm{wt} \%$ (corresponding to a fractional solubility of $\sim 1 \%$ ) and delivers much smaller Fe fluxes (0.02-0.07 Gmoles $\mathrm{yr}^{-1}$ to the Arctic Ocean and 0.0-

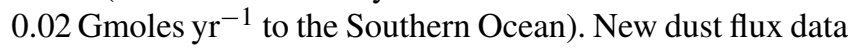
show that most atmospheric dust is delivered to sea ice where exposure to melting/re-freezing cycles may enhance fractional solubility, and thus fluxes, by a factor of approximately 2.5. Improved estimates for these particulate sources require additional data for the iceberg losses during fjord transit, the sediment content of icebergs, and samples of atmospheric dust delivered to the polar regions.
\end{abstract}

\section{Introduction}

Iron $(\mathrm{Fe})$ is an essential limiting nutrient for phytoplankton. Its supply exerts a significant impact on marine productivity with important implications for the carbon cycle and climate change (Mackenzie and Andersson, 2013). Quantifying Fe sources to the oceans, especially those that may be influenced by climate change, is therefore critical. Global Fe cycles commonly recognise important supplies of dissolved $\mathrm{Fe}$ ( $\mathrm{dFe},<0.2$ or $0.45 \mu \mathrm{m}$ ) from atmospheric dust, continental shelf sediments, and hydrothermal activity (e.g. Breitbarth et al., 2010). Iron isotopes are a promising novel approach (e.g. Conway and John, 2014) to quantifying these different sources but past contributions have commonly been based on estimates and/or measurements of $\mathrm{dFe}$ (see Tagliabue et al., 2010; Dale et al., 2015). However, quantifying dFe contributions from atmospheric dust requires an estimate of the solubility of iron. Estimating the solubility of $\mathrm{Fe}$ in particulates is particularly important to understanding the Fe cycle in the polar oceans where iceberg-hosted sediments are a source of bioavailable Fe (Smith et al., 2007; Raiswell et al., 2008; Hawkings et al., 2014; Duprat et al., 2016).

The Southern Ocean (SO) is the largest high nutrientlow chlorophyll area where productivity is limited by the delivery of Fe (e.g. Moore et al., 2013). Recent modelling 
studies in the SO have focussed on understanding the factors which control spatial variations in productivity but reach different conclusions due to different representations of the $\mathrm{Fe}$ cycle and different assumptions regarding $\mathrm{Fe}$ solubility and scavenging. For example, Tagliabue et al. (2009) modelled measurements of $\mathrm{dFe}$ derived from atmospheric dust and shelf sediments. Atmospheric dust entering seawater was assumed to have a fractional solubility (soluble Fe expressed as a percentage of total $\mathrm{Fe}$ ) of $0.5 \%$ with continued slower dissolution during sinking occurring at a rate of $0.0002 \%$ per day. Overall sediments were more important than atmospheric dust, although dust supplies dominated in some regions depending on the model assumptions used. Lancelot et al. (2009) modelled dFe supplies from atmospheric dust, iceberg melt, and shelf sediments. Sediments were the major source, iceberg melt was of lesser significance, and atmospheric dust (assumed to have fractional solubility of $2 \%$ ) had little influence. The models gave good agreement with patterns of phytoplankton growth but large uncertainties were acknowledged in the magnitude of these sources. Boyd et al. (2012) compared biological utilisation patterns using four mechanisms of Fe supply (vertical diffusivity in areas free of sea ice, iceberg melt, atmospheric dust, and shelf sediments) that were found to have substantial areal extent. Phytoplankton Fe utilisation was highest in regions supplied by Patagonian dust (using fractional solubilities varying from 1 to $10 \%$ ) and, to a lesser extent, shelf sediments. Wadley et al. (2014) compared the relative magnitudes and variations in supply of dFe from melting icebergs, shelf sediments and atmospheric dust. Sediments were again shown to be the most important source but considerable uncertainty was noted over the flux of Fe from iceberg-hosted sediments. Death et al. (2014) considered a range of sources that included iceberg-hosted sediments and atmospheric dust and found that modelled productivity was significantly enhanced in areas receiving iceberg-hosted sediments and subglacial melt compared to the productivity arising from atmospheric dust (assumed fractional solubility of $2 \%$ ). However, the contribution from iceberg-hosted sediments was based on a suite of only six samples (Raiswell et al., 2008) that contained $0.15 \mathrm{wt} \% \mathrm{Fe}$ as ferrihydrite.

These studies show that SO models produce significant differences in the relative magnitudes of the different $\mathrm{Fe}$ sources which complicate attempts to isolate overlapping contributions. For example, Tagliabue et al. (2016) show that

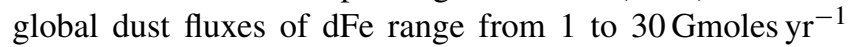
between different models. Few studies also count for iceberg sources of Fe (see Tagliabue et al., 2016; Table 1), the importance of which may be particularly sensitive to climate change. Climate change is driving increased loss of ice from ice shelves in the Antarctic Peninsula (Vaughan, 2006; Rignot et al., 2011) and ice-shelf shrinkage has also been reported from other areas of Antarctica (Pritchard et al., 2012; Depoorter et al., 2013; Duprat et al., 2016). Ice-shelf losses increase the delivery of potentially bioavailable $\mathrm{Fe}$
Table 1. Comparison of the FeA content of different size fractions of iceberg sediment.

\begin{tabular}{ll}
\hline Sample & $\%$ FeA \\
\hline Sieved $<1 \mathrm{~mm}$ & $0.175 \pm 0.005$ \\
Sieved $<250 \mu \mathrm{m}$ & $0.172 \pm 0.003$ \\
Sieved $<63 \mu \mathrm{m}$ & $0.162 \pm 0.010$ \\
\hline
\end{tabular}

by iceberg-hosted sediments. Unfortunately, iceberg-hosted sediment data are sparse but current estimates indicate Fe delivery appears to exceed meltwater delivery to the SO by at least an order of magnitude (Hawkings et al., 2014).

Increases in iceberg-hosted sediment delivery are also likely in the Arctic Ocean (AO). A relatively high proportion of primary production occurs on the AO shelves (Pabi et al., 2008) where ice-free areas experience intense phytoplankton blooms due to favourable light and nutrient conditions. Nitrate appears to be the primary limiting nutrient otherwise $\mathrm{Fe}$ and/or light become limiting (Popova et al., 2010). Hawkings et al. (2014) have estimated Fe delivery by meltwaters from the Greenland Ice Sheet but no data are available for Fe delivery from iceberg-hosted sediments, although marineterminating glaciers in the $\mathrm{AO}$ are likely to respond to climate change, as in the SO, by producing more icebergs (Bamber et al., 2012) and thus increasing sediment Fe delivery.

Modelling the polar Fe cycles and assessing the impact of climate change requires an improved estimate of the $\mathrm{Fe}$ currently released from the particulates present as iceberghosted sediments and atmospheric dust. There is a substantial disagreement as to the strength of different sources and reducing their uncertainty is important (Tagliabue et al., 2016). This contribution presents new data for potentially bioavailable Fe from iceberg-hosted sediments and atmospheric dust and also shows how ice transport and storage may influence $\mathrm{Fe}$ delivery to the polar regions. The $\mathrm{AO}$ and the SO differ in several important respects. The AO receives a substantial riverine flux ( $\sim 2400 \mathrm{~km}^{3} \mathrm{yr}^{-1}$; Dyurgerov et al., 2010), more atmospheric combustion products (Luo et al., 2008), has a proportionately smaller area of winter ice (see later) and is also being disproportionately affected by global warming (IPCC, 2013). Changes in Fe delivery to the SO may influence productivity but this is unlikely in the $\mathrm{AO}$ where there is no evidence for Fe limitation (except perhaps in summer in the Irminger Basin; Nielsdottir et al., 2009).

The $\mathrm{Fe}$ budgets for the $\mathrm{AO}$ use the area $>60^{\circ} \mathrm{N}$ (a larger area than that $>66.56^{\circ} \mathrm{N}$, which is conventionally used to define the Arctic Ocean; Pabi et al., 2008) and the SO budget is based on the area $>60^{\circ} \mathrm{S}$. The $60^{\circ} \mathrm{S}$ latitude lies close to the Antarctic Polar Front (the boundary between cold Antarctic waters and warmer sub-Antarctic waters), which runs clockwise from $140^{\circ} \mathrm{E}$ to $60^{\circ} \mathrm{W}$, beyond which the front moves out to $48^{\circ} \mathrm{S}$ (Moore et al., 1999). Our new flux estimates are based on measurements of ferrihydrite $\mathrm{Fe}$ which are deter- 
mined by the source and mode of delivery and have a fundamental influence on bioavailability. We are concerned only with glacial and atmospheric particulate sources that can be significantly influenced by terrestrial and/or transport processes prior to entry into seawater. The fate of these sources on entering seawater and their spatial variations are outside this focus although our data may inform these research areas.

\section{Methodology}

\subsection{Ice-hosted sediment sampling}

Over 60 sediment samples have been collected from icebergs and glaciers at 15 different Arctic and Antarctic locations (Table S1 in Supplement). Data have previously been reported for only 15 of these samples (from 7 localities; see Table S1) and thus the new samples provide a significant expansion of the existing data that now represent a substantial database for $\mathrm{Fe}$ in ice-hosted sediments. A set of 41 new iceberg samples were collected from floating icebergs with sediment-bearing layers present in dense, clear blue ice, indicating compressed glacier ice rather than accreted frozen seawater. An additional suite of nine new glacial ice samples was collected from sediment-rich bands in the main body of glaciers (i.e. land-based ice, not icebergs). These samples represent basal ice which has been in contact with the icerock interface.

Samples were collected with a clean ice axe, geological hammer, or chisel. The outer layers of ice that might be contaminated were allowed to melt and drain away before the remaining ice was transferred into a new polyethylene bag and allowed to melt. Some loss of dissolved Fe by adsorption or the precipitation of (oxyhydr)oxides during melting is possible (Conway et al., 2015), but the presence of organic complexes (see later) may stabilise dissolved $\mathrm{Fe}$. In any event, melt $\mathrm{dFe}$ concentrations are too low (Hawkings et al., 2014) to produce any significant increase in sediment Fe contents. Sediment samples were collected as soon as melting was complete by filtration through a Whatman $542(2.7 \mu \mathrm{m}$ pore diameter) filter paper or through a $0.4 / 0.45 \mu \mathrm{m}$ membrane filter (Table S3). There is a significant difference in the size fractions produced by filtration through $2.7 \mu \mathrm{m}$ and $0.4 / 0.45 \mu \mathrm{m}$; however, the filtered iceberg sediment is dominated by coarser material, and variations in the content and masses of the fraction passing through the different filters seem to be too small to produce significant differences in our extractable Fe contents, at least compared to the variations between different samples (see Tables 1, 3, and S3). Small pebbles and grit ( $>1 \mathrm{~mm}$ diameter) were removed and the remaining material gently disaggregated but not crushed. Any further separations are as described below.

\subsection{Atmospheric dust samples}

A suite of 15 atmospheric dust samples (Table S2) has been analysed by the same extraction techniques used for the iceberg and glacial samples to ensure data comparability. Seven new samples were collected during a cruise through the eastern tropical Atlantic and into the Sea of Marmara (Baker et al., 2006). Aerosol samples ( $\sim 100 \mathrm{mg}$ ) were collected using high-volume $\left(1 \mathrm{~m}^{3} \mathrm{~min}^{-1}\right)$ aerosol samplers onto single acid-washed Whatman 41 filters (pore size $20 \mu \mathrm{m}$; see Baker et al., 2006) and mainly represent mineral dust from the $\mathrm{Sa}$ hara. Three new samples of dry deposition were collected from a clean window in Southern Patagonia and two new samples of dry deposition were collected from the Eastern Mediterranean: one from a dust collector located in Crete and the other from deposition on to a clean glass surface at Rosh Pina, Israel (Table S2). These bulk mineral dust samples were collected after dust storms and are unlikely to be significantly affected by contamination (see Shi et al., 2009). Relevant data from the literature (Table S2) are also included for three additional dry deposition samples from the Eastern Mediterranean and China (Table S2).

\subsection{Analytical methodology}

Each sample of air-dried sediment was treated for $24 \mathrm{~h}$ by an ascorbic acid solution buffered at $\mathrm{pH} 7.5$. Air drying at room temperature does not achieve complete water loss but $<10 \mathrm{wt} \%$ more water is removed by oven drying. The extractant was a solution of $0.17 \mathrm{M}$ sodium citrate and $0.6 \mathrm{M}$ sodium bicarbonate to which ascorbic acid was added to produce a concentration of $0.057 \mathrm{M}$. This solution was deoxygenated (by bubbling with nitrogen; see Reyes and Torrent, 1997). Approximately $10-40 \mathrm{mg}$ of sample were mixed with $10 \mathrm{~mL}$ of the ascorbate solution, shaken for $24 \mathrm{~h}$ at room temperature and then filtered through a $0.45 \mu \mathrm{m}$ cellulose nitrate membrane filter (Kostka and Luther, 1994; Hyacinthe and Van Cappellen, 2004; Raiswell et al., 2010). The Fe removed by ascorbic acid is hereafter termed FeA and reported as dry wt $\%$. Controlling these conditions produces a high degree of selectivity. $\mathrm{Fe}$ is quantitatively removed from fresh two-line ferrihydrite and partially dissolved from aged twoline and six-line ferrihydrite and schwertmannite with negligible effects on other $\mathrm{Fe}$ (oxyhydr)oxides or clay minerals (Raiswell et al., 2010). The presence of ferrihydrite in iceberg-hosted sediment and subglacial sediment has been confirmed by high-resolution photomicrographs and selected area electron diffraction by Raiswell et al. (2008) and Hawkings et al. (2014).

Ferrihydrite only exists as a fine-grained and highly defective nanomaterial. The more disordered form (Hiemstra, 2013) contains two diffraction lines (two-line ferrihydrite, often called hydrous ferric oxide) and exists as smaller crystallites than the form with six diffraction lines (six-line ferrihydrite). The measurement of ferrihydrite is important be- 
cause this mineral phase is directly or indirectly bioavailable (Wells et al., 1983; Rich and Morel, 1990; Kuma and Matsunga, 1995; Nodwell and Price, 2001). The delivery of fresh ferrihydrite to the open ocean thus has the potential to stimulate productivity in Fe-limited areas (Raiswell et al., 2008; Raiswell, 2011).

The residual sediment was treated for $2 \mathrm{~h}$ with a solution of $0.29 \mathrm{M}$ sodium dithionite in $0.35 \mathrm{M}$ acetic acid and $0.2 \mathrm{M}$ sodium citrate, buffered at $\mathrm{pH} 4.8$ (Raiswell et al., 1994). Following the ascorbic acid extraction step, the dithionite extracts the remaining (oxyhydr)oxide Fe (aged ferrihydrite, goethite, lepidocrocite, and hematite; Raiswell et al., 1994). Dithionite-soluble $\mathrm{Fe}$ is hereafter termed FeD and is reported as dry wt \%. Both the FeA and FeD extractant solutions were analysed for Fe either by an atomic absorption spectrometer with an air-acetylene flame or by spectrophotometry using ferrozine (Stookey, 1970). Replicate analysis of a river sediment internal laboratory standard gave analytical precisions of $3 \%$ for $\mathrm{FeA}$ and $10 \%$ for $\mathrm{FeD}$ using this sequential extraction. Errors associated with sampling glacial sediments are examined below. Blank corrections were negligible.

\subsection{Approach}

Estimates of the solubility of $\mathrm{Fe}$ in atmospheric dust have utilised a variety of extraction techniques which have produced estimates of fractional solubility ranging from 0.2 to $80 \%$ (Jickells and Spokes, 2001), depending on time, pH, and the extractant (Baker and Croot, 2010). Recent studies have attempted to recognise a soluble Fe fraction (extracted with ultra-pure distilled water or seawater) and/or a labile or leachable fraction (using a low $\mathrm{pH}$ chemical extraction). Distilled water leaches (Sedwick et al., 2007; Berger et al., 2008; Conway et al., 2015) provide a consistent and reproducible result but losses of $\mathrm{Fe}$ can occur due to precipitation of $\mathrm{Fe}(\mathrm{OH})_{3}$. Rapid filtration or flow through techniques can be used to minimise such $\mathrm{Fe}$ losses. Seawater extractions are thought to be less reproducible due to variations in the concentrations of natural binding ligands (Sedwick et al., 2007).

Few of the extractions used to determine labile or leachable Fe have been fully calibrated against different Fe minerals. Baker et al. (2006) extracted Fe using ammonium acetate at $\mathrm{pH} 4.7$, which dissolves negligible concentrations of $\mathrm{Fe}$ (oxyhydr)oxides but significant concentrations of $\mathrm{Fe}$ as carbonate (Poulton and Canfield, 2005). Chen and Siefert (2003) extracted Fe with a $0.5 \mathrm{mM}$ formate-acetate buffer at $\mathrm{pH} 4.5$, which was stated to dissolve $\mathrm{Fe}$ (oxyhydr)oxides (mineralogy unspecified). Berger et al. (2008) use a pH 2 leach with acetic acid and hydroxylamine hydrochloride followed by a $10 \mathrm{~min}$ heating step at $90^{\circ} \mathrm{C}$. This method (Winton et al., 2015) extracts metals associated with biogenic material, Fe, and Mn (oxyhydr)oxides and adsorbed to clay minerals. Our ascorbic acid extraction is stronger than that by Baker et al. (2006) but weaker than the extractions used by Chen and Siefert (2003) and Berger et al. (2008). The ascorbic acid ex- traction is, however, selective for fresh ferrihydrite, which is the most soluble, and thus potentially bioavailable, $\mathrm{Fe}$ (oxyhydr)oxide mineral.

We recognise two particulate fractions (Raiswell and Canfield, 2012) that contain $\mathrm{Fe}$ (oxyhydr)oxide minerals (ferrihydrite, lepidocrocite, goethite, and hematite), as described below.

1. FeA reported as wt $\% \mathrm{Fe}$ that is extractable by ascorbic acid and consists mainly of fresh ferrihydrite (Raiswell et al., 2011).

2. FeD reported as wt $\% \mathrm{Fe}$ that is extractable by dithionite. Extraction of $\mathrm{FeD}$ following removal of FeA mainly dissolves residual, aged ferrihydrite plus lepidocrocite, goethite, and hematite (Raiswell et al., 1994).

An important issue concerns the bioavailability of FeA and FeD. Experimental work suggests that some part of sediment Fe can support plankton growth (Smith et al., 2007; Sugie et al., 2013). Sediment Fe present as fresh ferrihydrite (the most soluble $\mathrm{Fe}$ (oxyhydr)oxide) is directly or indirectly bioavailable (see above) and is extracted as FeA. FeA mainly comprises nanoparticulate ferrihydrite that probably encompasses a range in bioavailabilities (Shaked and Lis, 2012) due to variations in the extent of aggregation and associations with organic matter (which may partially or wholly envelope Fe (oxyhydr)oxide minerals; Raiswell and Canfield, 2012). We are concerned with Fe mineral reactivity at the point of delivery to seawater where ferrihydrite measured as $\mathrm{FeA}$ is more labile than $\mathrm{FeD}$ (the dithionite-soluble (oxyhydr)oxides which are relatively stable and poorly bioavailable). However, Fe present as FeD may become partially bioavailable after delivery to seawater (for example by dissolution and grazing; Barbeau et al., 1996; Shaked and Lis, 2012), but these complex interactions are outside the scope of the present contribution.

\section{Results and interpretation}

\subsection{Reproducibility of iceberg sediment sampling}

The collection of small samples from heterogeneous sediment with a range of grain sizes (clay up to sand size and beyond) is difficult to do reproducibly. Our approach has been to examine the variability both within and between different size fractions. Our previous practice (Raiswell et al., 2008) has been to remove only coarse material $>1 \mathrm{~mm}$ diameter, which might severely affect our ability to analyse sub-samples of $10-40 \mathrm{mg}$ reproducibly. Table 1 compares the composition of different size fractions produced by sieving iceberg sediment (from Wallenbergfjorden, Svalbard) first to $<1 \mathrm{~mm}$ and then by taking two further replicate subsamples: one sieved to $<250 \mu \mathrm{m}$ and the other to $<63 \mu \mathrm{m}$. Five replicates were analysed from each size fraction to give the means and standard deviations in Table 1. 
Table 2. Reproducibility of the $<1 \mathrm{~mm}$ fraction of iceberg sediments.

\begin{tabular}{lrr}
\hline Sample & $\% \mathrm{FeA}<1 \mathrm{~mm}$ & $\% \mathrm{FeA}<63 \mu \mathrm{m}$ \\
\hline $\mathrm{K} 1$ & $0.374 \pm 0.019$ & 0.377 \\
$\mathrm{~K} 2$ & $0.094 \pm 0.019$ & 0.056 \\
$\mathrm{~K} 3$ & $0.044 \pm 0.017$ & 0.058 \\
$\mathrm{~K} 4$ & $0.129 \pm 0.021$ & 0.102 \\
$\mathrm{~K} 5$ & $0.089 \pm 0.007$ & 0.134 \\
\hline
\end{tabular}

A Student's $t$ test showed no significant differences between mean analyses of wt $\% \mathrm{FeA}$ in the three different size fractions. In general the wt $\%$ FeA would be expected to be larger in the finer fractions, but the enrichment need not be large. A comparison of the FeA contents of the glacial flours studied by Hopwood et al. (2014) showed that $<500 \mu \mathrm{m}$ fractions contained $40-130 \%$ of the FeA content of the $<63 \mu \mathrm{m}$ fraction. Shaw et al. (2011) also found a rather similar wt $\%$ of $\mathrm{FeA}$ in the $63-125 \mu \mathrm{m}(0.038 \%)$ and $125-500 \mu \mathrm{m}(0.053 \%)$ fractions of iceberg sediment. Thus the finest fractions are not always large enough in mass, or have a high enough wt $\%$ FeA, to produce substantial differences between the different size fractions. We next examined the sampling reproducibility using five different iceberg samples (K1-5) from Kongsfjorden, Svalbard (see Table S3), that were sieved through $1 \mathrm{~mm}$ with a replicate subsample then produced by sieving to $<63 \mu \mathrm{m}$. Table 2 shows the mean and standard deviation for five replicate analyses of these iceberg samples sieved through $<1 \mathrm{~mm}$ and compared to a single analysis of the $<63 \mu \mathrm{m}$ fraction.

No consistent pattern emerged from the data presented in Table 2. Samples with low wt \% FeA values (K2 and K3) tended to show the most variation. However, a $z$ test showed a high probability of there being no significant difference between the $<1 \mathrm{~mm}$ and $<63 \mu \mathrm{m}$ samples for $\mathrm{K} 1, \mathrm{~K} 3$, and K5 $(p>5 \%)$ but a low probability $(p<0.2 \%)$ that samples $\mathrm{K} 2$ and $\mathrm{K} 4$ were not significantly different. We conclude that our practice of removing only very coarse material by sieving through $<1 \mathrm{~mm}$ provides a reasonable compromise that achieves good reproducibility (unless the wt $\% \mathrm{FeA}$ is less than $0.05 \%$ ) in samples that are coarse enough to be representative of the sediments delivered by icebergs.

\subsection{Ice-hosted sediment composition}

Table 3 summarises the wt $\% \mathrm{FeA}$ and $\mathrm{FeD}$ contents of the iceberg and glacier sediments and the mean and standard deviations of $\mathrm{FeA}$ and $\mathrm{FeD}$. Wide variations mainly result from source area geology but there are no significant differences between the compositions of the Arctic and Antarctic icebergs (when the outlying data for Weddell Sea IRD4 are ignored; see Table S3) and hence we are justified in presenting all the iceberg samples as a single group (Table 3 ).
The wt $\% \mathrm{FeA}$ and $\mathrm{FeD}$ data approach a log-normal distribution and hence logarithmic means are used to calculate the mean values and the logarithmic standard deviations are used to derive the low and high values in Table 3 . This approach produces a logarithmic mean FeA content of $0.076 \mathrm{wt} \%$ for the iceberg sediments and a range of 0.030 to $0.194 \%$. These new values are based on more than 50 iceberg samples; thus this mean is more reliable than the earlier mean value of $0.15 \mathrm{wt} \% \mathrm{FeA}$ (based on only six samples from Raiswell et al., 2008) and the large number of samples also permit an estimate of the variation. A Student's $t$ test on the logarithmic data showed that the iceberg sediments are significantly higher $(p<0.1 \%)$ than the logarithmic mean and standard deviation of the wt \% FeA contents of the sediments from glacial ice (mean $0.03 \%$; range 0.015 to $0.060 \%$ ). The logarithmic mean and standard deviation of the values for wt $\%$ $\mathrm{FeD}$ in Table 3 are also significantly higher $(p<0.1 \%)$ in the icebergs (mean $0.377 \%$; range 0.20 to $0.715 \%$ ) than in the sediments from glacial ice (mean $0.091 \%$; range 0.042 to $0.196 \%$ ).

\section{Ice processing effects}

The wt $\% \mathrm{FeA}$ and FeD contents of the iceberg sediments are significantly higher than the glacier-hosted sediments. The icebergs were not all derived from the land-based glaciers we sampled, and part of the differences in FeA and FeD may result from mineralogical/geochemical variations in the glacial bedrock. An alternative explanation for the high wt $\% \mathrm{FeA}$ and $\mathrm{FeD}$ values is that iceberg sediments have undergone alteration during post-calving transport as temperature fluctuations induced melting/freezing cycles that caused dissolution and precipitation. The slightly acidic $\mathrm{pH}(5.5-6.0)$ of glacial ice melt (Meguro et al., 2004; Tranter and Jones, 2001) accompanied by the presence of extracellular polymeric substances (EPS) (Lannuzel et al., 2014; Lutz et al., 2014; Hassler et al., 2011, 2015) is able to accelerate the dissolution of Fe (oxyhydr)oxides.

Experimental work by Jeong et al. (2012) showed enhanced dissolution rates of goethite and hematite trapped in ice compared to dissolution rates in water. The degree of enhancement depended on the presence of organic ligands and the surface area of the iron (oxyhydr)oxides; thus the high surface area of ferrihydrite (compared to goethite and hematite) should produce large enhancements. Jeong et al. (2012) found that dissolution was ligand-enhanced and not reductive. However, Kim et al. (2010) have also observed that $\mathrm{UV}$ radiation causes the photoreductive dissolution of $\mathrm{Fe}$ (oxyhydr)oxides (goethite, hematite) encased in ice to ferrous Fe. Photoreductive dissolution was significantly faster in ice than in aqueous solutions at $\mathrm{pH} 3.5$ (and was 7-8 times faster than the dissolution rates observed by Jeong et al., 2012) and was not influenced by the presence of electron donors. Acids are concentrated by several orders of magnitude at the ice-grain boundary due to freeze concentration ef- 
Table 3. Composition of iceberg, glacial ice, and atmospheric dust samples (number of samples in brackets).

\begin{tabular}{lrrrrrrr}
\hline Sample & \multicolumn{3}{c}{$\begin{array}{c}\text { wt \%FeA } \\
\text { Lean }\end{array}$} & High & Low & Mean $\%$ HeD & High $\begin{array}{r}\text { (FeA+FeD) } / \mathrm{FeT} \\
\text { estimated range } \\
\text { (see text) }\end{array}$ \\
\hline Icebergs (51) & 0.03 & 0.076 & 0.194 & 0.20 & 0.377 & 0.715 & $0.063-0.201$ \\
Glacial ice (16) & 0.015 & 0.03 & 0.060 & 0.042 & 0.091 & 0.196 & $0.013-0.059$ \\
Atmospheric dust (15) & 0.018 & 0.038 & 0.081 & 0.428 & 0.868 & 1.76 & $0.24-0.52$ \\
\hline
\end{tabular}

Low and high values each represent 1 logarithmic standard deviation from the logarithmic mean, except for $(\mathrm{FeA}+\mathrm{FeD}) / \mathrm{FeT}$.

fects, and the resulting low $\mathrm{pH}(\sim 1.5)$ further enhances both ligand and reductive dissolution (Kim et al., 2010; Jeong et al., 2015). Lin and Twinning (2012) have found elevated concentrations of ferrous Fe within $1 \mathrm{~km}$ of a melting iceberg in the Southern Ocean, which they suggest could be derived by the photoreduction of FeA in melt pools. However, most ferrous $\mathrm{Fe}$ is likely to be rapidly re-oxidised and precipitated as (oxyhydr)oxide minerals once exposed to the atmosphere by melting, which dilutes the acids and increases $\mathrm{pH}$. The dissolution/precipitation effects of repeated melting/freezing events are explored below, as they might apply to any sediments (including atmospheric dust, see later) encased in ice.

Figure 1 shows an idealised melting/freezing reaction scheme for any sediment in which Fe (oxyhydr)oxides are initially absent and that only contains silicate Fe. Dissolution is initiated in acidic snow melt where Fe is leached slowly by silicate dissolution (Step 1). Subsequent freezing initially concentrates the acids and accelerates dissolution until complete freezing (or consumption of the acids) halts dissolution and induces the precipitation and aggregation of Fe (oxyhydr)oxides as FeA and FeD (Step 2). The transformation of ferrihydrite $(\mathrm{FeA})$ to goethite/hematite $(\mathrm{FeD})$ has a halflife of several years at $t<5^{\circ} \mathrm{C}$ (Schwertmann et al., 2004; Brinza, 2010) and hence a proportion of FeA can be preserved over the life time of an iceberg. A new phase of melting (Step 3) causes the dissolution or disaggregation of the newly formed FeA and FeD and also restarts the slow dissolution of silicate Fe. Renewed freezing again accelerates dissolution but finally precipitates FeA and FeD in amounts (Step 4) that have now been increased by the Step 3 dissolution of silicate Fe. Provided there is insufficient time for the transformation of FeA to FeD to be completed then FeA and FeD will both accumulate at the expense of silicate Fe. A comparison of the logarithmic mean FeA contents of the glacial $(0.03 \mathrm{wt} \%)$ and iceberg $(0.076 \mathrm{wt} \%)$ sediments and their errors suggests that melting/freezing effects, hereafter termed "ice processing", could increase FeA contents by factor of 2.5, assuming similar initial FeA contents. These data provide the first, semi-quantitative, estimate of how deposition on to sea ice might enhance the FeA delivery from atmospheric dust. These changes may also be accompanied by other, poorly understood, chemical mechanisms that may fur-

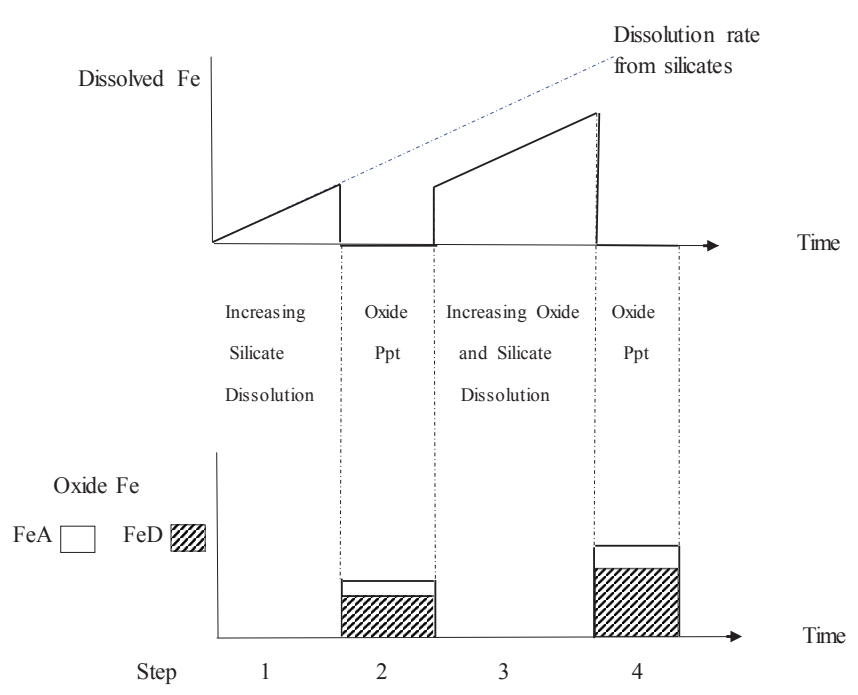

Figure 1. Simplified reaction scheme for the behaviour of icehosted sediments during melting/freezing cycles.

ther enhance Fe delivery from sea ice (Vancoppenolle et al., 2013).

\subsection{Iceberg-hosted FeA fluxes}

The iceberg-hosted FeA flux (Table 4) is based on sediment encased in icebergs and excludes sediments associated with seasonal ice (see later). The solid ice discharge from Antarctica has been determined as $1321 \pm 144 \mathrm{~km}^{3} \mathrm{yr}^{-1}$ by Depoorter et al. (2013) for the period 1979-2010 and from Greenland as $524 \pm 51 \mathrm{~km}^{3} \mathrm{yr}^{-1}$ for the period 1958-2010 by Bamber et al. (2012). Van Wychen et al. (2014) estimate that the contribution from other ice masses in Alaska, Svalbard, and the Russian and Canadian Arctic is $34.4 \mathrm{~km}^{3} \mathrm{yr}^{-1}$, for which we assume a $10 \%$ error (roughly the same as for the Greenland flux). Hence the total ice loss from the Arctic is $558 \pm 55 \mathrm{~km}^{3} \mathrm{yr}^{-1}$ and from the Antarctic is $1321 \pm 144 \mathrm{~km}^{3} \mathrm{yr}^{-1}$. Iceberg-hosted sediment FeA delivery can in theory be estimated from the product of ice mass loss, iceberg-sediment content, and FeA concentration but there are significant difficulties.

The ice mass loss does not represent the mass of icebergs delivered into coastal waters, as significant melting may oc- 
Table 4. Fluxes of FeA derived from iceberg-hosted sediment by melting.

\begin{tabular}{lrrl}
\hline & Arctic & Antarctic & Sources/notes \\
\hline Ice discharge $\mathrm{km}^{3} \mathrm{yr}^{-1}$ & $279 \pm 27$ (a) & $1321 \pm 144$ (b) & $\begin{array}{l}\text { (a) Bamber et al. (2012) and } \\
\text { Van Wychen et al. (2014); } \\
\text { assumes 50 \% fjord losses. } \\
\text { (b) Depoorter et al (2013). }\end{array}$ \\
\hline Sediment content g L & & 0.5 (c) & $\begin{array}{l}\text { (c) Poorly constrained estimate } \\
\text { by Raiswell et al. (2006), } \\
\text { similar to the mean river load } \\
\text { (see text). }\end{array}$ \\
\hline FeA wt \% & 0.5 (c) & & \\
\hline FeA flux Gmol yr & & $0.03-0.076-0.194$ & \\
\hline
\end{tabular}

cur for glaciers that calve into long fjords (Hopwood et al., 2016). Such losses are relatively small in Antarctica where most icebergs are calved from massive, marine-terminating ice shelves and the remainder from outlet glaciers that calve directly into the sea (Silva et al., 2006; Diemand, 2008). However, the characteristics of Greenlandic glaciers vary. One endmember represents fast moving glaciers where the ice mass loss is mostly by calving into the ocean, and the other endmember represents glaciers entering long (up to $100 \mathrm{~km}$ ) fjords where the ice mass loss is mainly by melting in the fjord (Straneo and Cedenese, 2015; Hopwood et al., 2016). For this latter endmember, fjord circulation patterns largely prevent iceberg-hosted sediments from being delivered directly to coastal waters (Hopwood et al., 2015, 2016). However, the five largest ice mass losses from Greenlandic glaciers occur from the Jakobshavn, Køge Bugt, Ikertivaq, Kangerdlugssuaq, and Helheim glaciers (together representing an ice mass loss of $\sim 135 \mathrm{~km}^{3} \mathrm{yr}^{-1}$; Enderlin et al., 2014). The first three of these glaciers either calve directly into coastal waters or have relatively short fjord transit times or distances where melting losses should be low, while large icebergs have also been observed to drift $>150 \mathrm{~km}$ out of Sermilik Fjord (Helheim Glacier; Sutherland et al., 2014). The Jakobshavn, Køge Bugt, and Ikertivaq glaciers deliver approximately $68 \%$ of the $135 \mathrm{~km}^{3} \mathrm{yr}^{-1}$ directly to coastal waters. Data on fjord mass losses are urgently required but we will proceed by assuming that melting losses are negligible in Antarctica and are $50 \%$ in the Arctic. Thus the ice discharge to the $\mathrm{AO}$ is estimated to be $279 \pm 27 \mathrm{~km}^{3} \mathrm{yr}^{-1}$ (Table 4).

Raiswell et al. (2006) and Death et al. (2014) point out that the sediment content of icebergs is poorly constrained but use a value of $0.5 \mathrm{~g}$ litre ${ }^{-1}$, similar to the mean sediment content of river water. Death et al. (2014) cite a range of 0.4$0.8 \mathrm{~g} \mathrm{~L}^{-1}$ for Antarctic icebergs and a range $0.6-1.2 \mathrm{~g} \mathrm{~L}^{-1}$ has been inferred by Shaw et al. (2011) based on the sediment load needed to produce the excess ${ }^{224} \mathrm{Ra}$ activity in the vicinity of icebergs in the Weddell Sea. Substantially larger concentrations $\left(0.2-200 \mathrm{~g} \mathrm{~L}^{-1}\right)$ have been found by
Dowdeswell and Dowdeswell (1989). Here we use the conservative estimate of $0.5 \mathrm{~g}$ litre $^{-1}$ of sediment but this value may be a significant source of error. The mean wt $\% \mathrm{FeA}$ content of icebergs is $0.076 \%$ with a variability of 0.030 to $0.194 \%$ (Table 3). Deriving the product of the ice mass loss, sediment load, and FeA content (Table 4) shows that the flux of iceberg-hosted $\mathrm{FeA}$ to the $\mathrm{AO}$ ranges from 0.7 to $5.5 \mathrm{Gmol} \mathrm{yr}^{-1}$, with a mean of $1.9 \mathrm{Gmol} \mathrm{yr}^{-1}$, and to the SO is 3.2 to $25 \mathrm{Gmol} \mathrm{yr}^{-1}$, with a mean of $9.0 \mathrm{Gmol} \mathrm{yr}^{-1}$. The estimated ranges span an order of magnitude and hence all flux values hereon are only quoted to two significant figures.

\subsection{Atmospheric dust composition}

Mineralogy is a key factor in comparing particulate sources, and use of the ascorbic acid extraction technique for the iceberg sediments and atmospheric dust enables their ferrihydrite contents (as the most readily soluble and potentially bioavailable Fe mineral) to be compared. The atmospheric dust sample set is relatively small and mainly includes samples that are unlikely to be delivered to the polar regions, although Patagonian dust is a possible source to the SO (e.g. Schulz et al., 2012). Our Patagonian dust sample set is small but a Student's $t$ test indicates that there are no significant differences in the concentrations of $\mathrm{FeA}$ and $\mathrm{FeD}$ between the Patagonian dust and the other dust analysed here. Consistent with this we note that the range of total $\mathrm{Fe}$ values (2.9 to $4.3 \mathrm{wt} \%$ ) for the Patagonian aeolian dust analysed by Gaiero et al. (2007) overlaps the range in our dust (2.8-4.5 wt \%; Table S4) and the mean value of $3.5 \mathrm{wt} \%$ commonly assumed for atmospheric dust (e.g. Gao et al., 2003; Shi et al., 2012).

Our dust wt \% FeA contents are low (mean $0.038 \%$; range 0.018 to $0.081 \%$ ) and are comparable to the wt \% FeA contents of the sediments present in glacial ice, but significantly lower $(p<1 \%)$ than the iceberg-hosted sediments (Table 3). Assuming a dust total $\mathrm{Fe}(\mathrm{FeT})$ of $3.5 \mathrm{wt} \%$, the range in wt \% $\mathrm{FeA}$ corresponds to a fractional solubility of $\sim 1 \%$. These data provide a justification for the commonly used fractional 
solubility range of $1-2 \%$ (see earlier), which is known to be an arbitrary choice (Boyd et al., 2010). However, our ascorbic acid fractional solubility data are difficult to compare with literature values because a wide range of extractions have been used, few of which have been calibrated against ferrihydrite (see earlier). Conway et al. (2015) measure fractional solubility based on the ratio between $\mathrm{Fe}$ extracted at pH 5.3 by meltwater and total Fe. A median fractional solubility value of $6 \%$ was found for dust (deposited during the Last Glacial Maximum on ice at Dome C, East Antarctica) that was high in total $\mathrm{Fe}(8 \mathrm{wt} \%)$, possibly due to enrichment in smaller particles as a consequence of long-range transport. Rather lower fractional solubility values $(\sim 3 \%)$ were found at Berkner Island (closer to the South American dust sources) and these data are comparable to the FeA range of our dust data, assuming similar extraction behaviour.

Dust wt $\% \mathrm{FeD}$ values (mean $0.87 \%$; range 0.43 to $1.76 \%)$ are significantly higher $(p<0.1 \%)$ than in both iceberg and glacial ice sediments. These data suggest that the net effect of weathering and atmospheric/cloud processing (Shi et al., 2015) on our atmospheric dust has more than doubled $\mathrm{Fe}$ (oxyhydr)oxides present as the less reactive FeD. The influence of weathering effects alone on soils (potential dust precursors) has been studied by Shi et al. (2011), who showed that the ratio $(\mathrm{FeA}+\mathrm{FeD}) / \mathrm{FeT}$ increased from $0.1-0.2$ to $0.5-0.6$ in highly weathered samples from areas with relatively high rainfall and temperatures. The $(\mathrm{FeA}+\mathrm{FeD}) / \mathrm{FeT}$ values for the atmospheric dust in Table 3 range from 0.24 to 0.52 , which is clearly achievable by weathering alone in the source area. Values of ( $\mathrm{FeA}+\mathrm{FeD}) / \mathrm{FeT}$ for the glacial (range 0.013 to 0.059) and iceberg (range 0.063 to 0.201 ) sediments can also be estimated assuming $\mathrm{FeT}=4.2 \%$ (mean value for glacial sediments from Poulton and Raiswell, 2002). These values also suggest a trend of increasing weathering intensity from the glacial to the iceberg sediments (resulting from ice processing effects, see earlier) and to the atmospheric dust. Further data from atmospheric dust delivered to the polar regions are clearly needed to substantiate this conclusion.

\subsection{Atmospheric dust FeA fluxes}

This FeA flux is based on dust transported through the atmosphere where there is potential for processing (see above) and excludes soils. Localised areas of the Ross Sea are subject to large dust inputs from local terrestrial sands and silts but these appear to be only minor contributors to productivity (Chewings et al., 2014; Winton et al., 2014). Here we proceed cautiously on the basis that the FeA content of our atmospheric dust represents mineral dust (with small to negligible contributions from combustion sources) delivered to the polar regions. Dust deposition fluxes to the SO have been variably estimated as 0.1 to $27 \mathrm{Tg} \mathrm{yr}^{-1}$ (Gao et al., 2003; Mahowald et al., 2005; Jickells et al., 2005; Li et al., 2008). The new flux estimates derived here are based on the Commu- nity Earth System Model (Albani et al., 2014), which produces a value of $0.84 \mathrm{Tg} \mathrm{yr}^{-1}$ for dust deposition to the SO. The model version we use has been extensively compared to observations, with the sources modified to best match dust fluxes at high latitude (Albani et al., 2014). In the absence of ice processing, atmospheric dust delivered to the $\mathrm{SO}$ with an FeA wt \% ranging 0.018 to $0.081 \%$ produces a flux of $<0.01$ to 0.02 (mean 0.01 ) $\mathrm{Gmol} \mathrm{yr}^{-1}$ (Table 5). This corresponds to a flux of 0.14 to $0.64 \mu \mathrm{mol} \mathrm{m}^{-2} \mathrm{yr}^{-1}$ (assuming an area of $19 \times 10^{6} \mathrm{~km}^{2}$ for the SO).

Comparisons with other Fe flux estimates are difficult due to the different methodologies used. Edwards and Sedwick (2001) measured Fe soluble at $\mathrm{pH} 2$ from snow samples from East Antarctica, deriving a deposition flux of 0.3 to $2.0 \mu \mathrm{mol} \mathrm{m}{ }^{-2} \mathrm{yr}^{-1}$. Winton et al. (2015) used an acetic acid plus hydroxylamine hydrochloride extraction (at $\mathrm{pH} 2$ ) to estimate a flux of 0.64 to $2.5 \mu \mathrm{mol} \mathrm{m}{ }^{-2} \mathrm{yr}^{-1}$ for dust being delivered to a sector of the $\mathrm{SO}>45^{\circ} \mathrm{S}$. Both sites are believed to sample clean air with little addition from combustion sources. Our FeA data are at the low end of these estimates (consistent with the higher $\mathrm{pH}$ of our ascorbic acid extraction) and suggest that our FeA data provide a reasonable benchmark to compare mineral dust (in the absence of combustion addition) and iceberg fluxes delivered to the SO.

However, the SO is more than $80 \%$ covered by sea ice during winter (declining to a minimum of $\sim 16 \%$ ), which has residence time of 1-2 years (Vancoppenolle et al., 2013). Studies of sea ice show that it can be enriched in Fe by up to 2-3 orders of magnitude relative to the underlying seawater, and the melting edge is commonly associated with plankton blooms (Lannuzel et al., 2007, 2008, 2014). This Fe is derived from more sources than that in icebergs and includes atmospheric dust deposited on the ice surface (augmented by lithogenic dust in near-shore regions) and $\mathrm{Fe}$ scavenged from seawater during sea ice formation (Vancoppenolle et al., 2013; Wang et al., 2014). Studies of sea ice in Antarctica have shown high concentrations of Fe that are accompanied by EPS able to solubilise and complex Fe (Lannuzel et al., 2014). We suggest that atmospheric dust deposited on sea ice be processed by melting/refreezing cycle(s) in a similar fashion as dust deposited on icebergs where dust is dissolved (at low pH and aided by EPS) and photoreduced. Our comparison between glacier and iceberg wt $\% \mathrm{FeA}$ contents (Table 3 ) indicates that this ice processing has the potential to increase mean wt \% FeA contents by a factor of 2.5 from 0.038 to 0.095 wt \%. Simulations with the Community Earth System Model (Albani et al., 2014) representing the annual cycle of sea ice show that $0.6 \mathrm{Tg} \mathrm{yr}^{-1}$ of atmospheric dust are deposited on sea ice that melts (enabling ice processing to occur), which produces a mean rate of FeA delivery of $0.01 \mathrm{Gmol} \mathrm{yr}^{-1}$ with a range from $<0.01$ to $0.02 \mathrm{Gmol} \mathrm{yr}^{-1}$. A further $0.24 \mathrm{Tg} \mathrm{yr}^{-1}$ are deposited on open water (no ice processing), which supplies only small

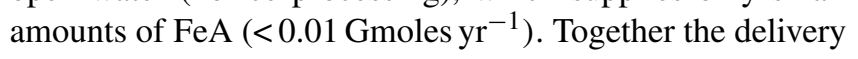


Table 5. Atmospheric dust FeA fluxes.

\begin{tabular}{|c|c|c|c|}
\hline & Arctic & Antarctic & Sources/notes \\
\hline Mass flux $\mathrm{Tg} \mathrm{yr}^{-1}$ & 5.1 & 0.84 & $\begin{array}{l}\text { Community Earth Systems } \\
\text { Model (Albani et al., 2014). }\end{array}$ \\
\hline FeA wt \% (no ice processing) & $0.018-0.038-0.081$ & $0.018-0.038-0.081$ & $\begin{array}{l}\text { Based on } 15 \text { dust samples } \\
\text { from the Atlantic, Mediter- } \\
\text { ranean, and Patagonia with lit- } \\
\text { tle } \\
\text { combustion inputs. }\end{array}$ \\
\hline FeA flux $\mathrm{Gmol} \mathrm{yr}^{-1}$ & $0.02-0.03-0.07$ & $<0.01-0.01-0.02$ & $\begin{array}{l}\text { Combustion inputs may range } \\
\text { up to similar levels. }\end{array}$ \\
\hline FeA wt $\%$ (with ice processing) & $0.045-0.095-0.203$ & $0.045-0.095-0.203$ & $\begin{array}{l}\text { Assuming ice processing } \\
\text { increases concentrations } 2.5 \\
\text { times. }\end{array}$ \\
\hline FeA flux $\mathrm{Gmol} \mathrm{yr}^{-1}$ & $0.03-0.05-0.12$ & $<0.01-0.01-0.03$ & \\
\hline
\end{tabular}

to sea ice and open water supplies a mean of $0.01 \mathrm{Gmol} \mathrm{yr}^{-1}$ with a range from $<0.01$ to $0.03 \mathrm{Gmol} \mathrm{yr}^{-1}$ (Table 5).

New dust Fe flux estimates to the $\mathrm{AO}\left(5.1 \mathrm{Tg} \mathrm{yr}^{-1}\right)$ are also derived from the Community Earth System Model (Albani et al., 2014) as before. In the absence of ice processing, a mass flux of $5.1 \mathrm{Tg} \mathrm{yr}^{-1}$ dust delivers a range of 0.02 to 0.07 (mean 0.03 ) $\mathrm{Gmol} \mathrm{yr}^{-1}$ of FeA (Table 5). Sea ice in the Arctic has a maximum extent of $<60 \%$ with a residence time of 1-7 years (Vancoppenolle et al., 2013). That part of the dust flux that falls on sea ice $\left(2.1 \mathrm{Tg} \mathrm{yr}^{-1}\right)$ may be altered by ice processing which increases the wt $\%$ FeA by a factor of 2.5 (see above) before being released by melting, as with the SO. Ice-processed dust delivery to the AO provides a mean FeA flux of $0.03 \mathrm{Gmol} \mathrm{yr}^{-1}$ with a range of 0.02 to $0.08 \mathrm{Gmol} \mathrm{yr}^{-1}$. The $3.0 \mathrm{Tg} \mathrm{yr}^{-1}$ of dust delivered to open

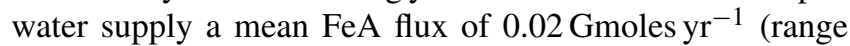
0.01 to $0.04 \mathrm{Gmol} \mathrm{yr}^{-1}$ ) and the total delivery (Table 5) to the $\mathrm{AO}$ is the sum of both fluxes (mean $0.05 \mathrm{Gmol} \mathrm{yr}^{-1}$; range 0.03 to $0.12 \mathrm{Gmol} \mathrm{yr}^{-1}$ ).

\section{Discussion and synthesis}

The new iceberg and atmospheric dust data presented here provide a valuable insight into the iceberg and dust Fe sources to the polar oceans. They substantiate the view that iceberg sediments have the potential to be a significant source of bioavailable $\mathrm{Fe}$ as ferrihydrite (Table 6). We provide a context for the iceberg sediment flux data by using the global shelf flux value of Dale et al. (2015) to derive an order of magnitude estimate of shelf sources (thought to be a dominant source in the SO, see earlier). The Arctic and Antarctic shelf areas represent 11.5 and $7.3 \%$ of the global shelf area ( $<200 \mathrm{~m}$ depth; Jahnke, 2010). Combining these area percentages with the global shelf flux dFe value of $72 \mathrm{Gmol} \mathrm{yr}^{-1}$
Table 6. Summary data for the main sources of iron to the Arctic and Southern oceans.

\begin{tabular}{lrr}
\hline Source & \multicolumn{2}{c}{ FeA flux range $\mathrm{Gmol} \mathrm{yr}^{-1}$} \\
& Arctic Ocean & Southern Ocean \\
\hline Iceberg sediments & $0.7-5.5$ & $3.2-25$ \\
Atmospheric dust & & \\
Ice processed & $0.03-0.12$ & $<0.01-0.03$ \\
No ice processing & $0.02-0.07$ & $<0.01-0.02$ \\
\hline
\end{tabular}

(Dale et al., 2015) suggests shelf sources are approximately $8.3 \mathrm{Gmol} \mathrm{yr}^{-1}$ to the AO and $5.3 \mathrm{Gmol} \mathrm{yr}^{-1}$ to the SO. The shelf areas of the AO and SO that are able to source shelf fluxes of iron are unknown and the values suggested here may be an overestimation. Furthermore, shelf dFe (largely colloidal or nanoparticulate Fe of unknown composition) and FeA as ferrihydrite may not be of similar bioavailability. Nevertheless, the ranges of the shelf and iceberg suggest that both are comparably important sources.

Sources of variation in Tables 4 and 5 relate both to the estimates of mass fluxes as well as the Fe analytical data but improved mass flux estimates may be difficult to achieve given their temporal and spatial variability. Table 6 and Fig. 2 summarise the flux ranges. At first sight there appear to be broad similarities in the magnitude of these Fe sources to the polar oceans but we list below three limitations to the current data set.

The iceberg FeA fluxes are based on data that are derived mainly from the Arctic. Iceberg melting losses during fjord transit are poorly known and, if underestimated here, might increase differences between the AO and the SO.

The atmospheric dust sample set is small and may not be representative of dust delivered to the polar regions. 


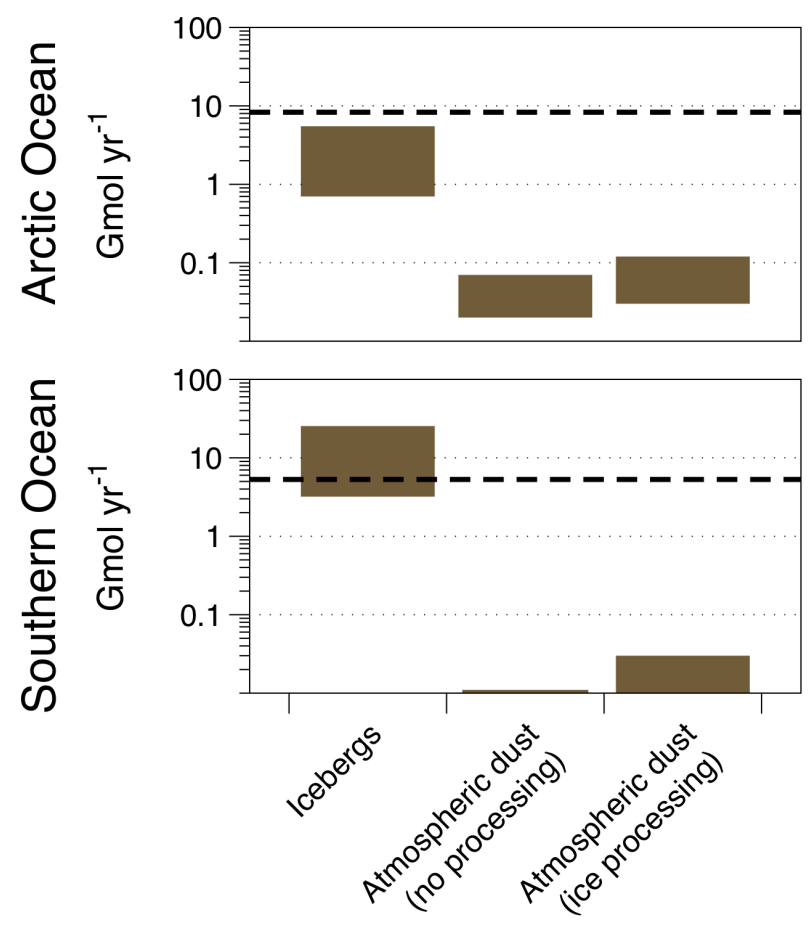

Figure 2. Ranges of FeA fluxes to the Arctic and Southern oceans. Dashed line shows rough estimates of shelf $\mathrm{dFe}$ based on Dale et al. (2015).

FeA is present as ferrihydrite, which is potentially bioavailable to phytoplankton although acquisition rates are unknown and may vary substantially between organisms and with local environmental factors (Shaked and Lis, 2012).

Iceberg-derived $\mathrm{FeA}$ is a major source of $\mathrm{Fe}$ to both the $\mathrm{AO}$ and the SO that will likely increase as iceberg delivery increases with climate warming in the polar regions (Table 6 and Fig. 2). Our measurements of iceberg FeA contents are based on a substantial data set, although Antarctic data are still poorly represented. It is clear that iceberg $\mathrm{FeA}$ is a major source of potentially bioavailable $\mathrm{Fe}$ as ferrihydrite, unless the errors associated with the estimates of iceberg sediment contents exceed an order of magnitude (Raiswell et al., 2008; Death et al., 2014; Hawkings et al., 2014). Modelling the impact of iceberg FeA delivery on surface water $\mathrm{dFe}$ concentrations will be complex and will require kinetic models that incorporate scavenging, complexation, dissolution, and sinking (e.g. Tagliabue and Volker, 2011; Raiswell and Canfield, 2012). FeA attached to coarse material will settle out of surface waters quickly, but FeA present mainly as finegrained material (or nanoparticles) may be held in suspension for long periods in the wake of icebergs. The basal and sidewall melt from icebergs creates complex patterns of upwelling and turbulence producing a persistent water column structure that may last for several weeks and whose influence extends for tens of kilometres and from the surface to 200-1500 m depth (Smith et al., 2013). Furthermore, giant icebergs ( $>18 \mathrm{~km}$ in length) have a disproportionally large areal influence (compared to smaller bergs) which may last for longer than a month (Duprat et al., 2016). The proportion of the FeA found within this area of influence will clearly have a prolonged residence time that may be a key factor in its dispersion and utilisation away from iceberg trajectories into areas where other Fe supplies are limited.

Atmospheric dust fluxes are estimated to be a minor source of $\mathrm{FeA}$ to both the $\mathrm{AO}$ and the SO, compared to iceberghosted sediment, although substantially larger to the AO (Table 6). The dust database used here is small but appears to be globally representative of mineral dust in that the range of wt $\%$ FeD contents ( $2-5 \%$ ) overlaps that found in other studies (e.g. Lafon et al., 2004, 2006). There are no comparable data for potential dust sources to the polar regions although Patagonia atmospheric dust (Gaiero et al., 2007) has wt \% total $\mathrm{Fe}$ values ranging from 2.9 to $4.3 \mathrm{wt} \%$ (which overlaps the $3.5 \mathrm{wt} \%$ total Fe value commonly used as a global average). Our mineral dust flux estimates could be significantly increased by combustion sources, estimates of which are very dependent on the flux model assumptions, especially those for Fe solubility. Luo et al. (2008) show global maps of the ratio (soluble $\mathrm{Fe}$ from combustion)/(total soluble $\mathrm{Fe}$ ) which ranges from 10 to $40 \%$ in the $\mathrm{SO}\left(>60^{\circ} \mathrm{S}\right)$ and 20 to $60 \%$ in the $\mathrm{AO}\left(>60^{\circ} \mathrm{N}\right)$. Ito $(2015)$ also shows that soluble $\mathrm{Fe}$ from dust makes up $\sim 50 \%$ of the total soluble Fe. Table 5 acknowledges that combustion sources could be as large as that from dust in some areas of the $\mathrm{AO}$ and the SO.

The important features of the new FeA and FeD dust data presented here is that they are closely tied to mineralogy, with FeA measuring the content of fresh ferrihydrite, which is the most reactive and potentially bioavailable Fe mineral. Thus these data enable direct comparison with iceberg sediment FeA delivery. Furthermore we have estimated a potential role for ice processing which appears to enhance FeA contents of dust delivered to sea ice. Mean dust FeA concentrations of $0.095 \mathrm{wt} \%$ (if ice processed) approximate to the mean concentration in icebergs $(0.076 \mathrm{wt} \%)$, which indicates that the former will dominate in areas where dust mass fluxes exceed iceberg sediment delivery, assuming both types of particulates have similar residence times in the ocean. Additional atmospheric dust samples from the polar regions are needed to support these cautious conclusions and to clarify the role of combustion sources. Wet deposition is thought to be the main mechanism of deposition to the SO but fluxes are poorly known (Mahowald et al., 2011). Very high soluble Fe contents (Heimburger et al., 2013) have been found in wet deposition samples from the Kerguelen Islands (at $48^{\circ} \mathrm{S}$, which lies outside our SO area) and a similar flux to the area $>60^{\circ} \mathrm{S}$ would represent a major contribution.

\section{Information about the Supplement}

All the data used in this manuscript are included in the Supplement. 


\section{The Supplement related to this article is available online at doi:10.5194/bg-13-3887-2016-supplement.}

Acknowledgements. Robert Raiswell thanks the School of Earth and Environment for Greenland fieldwork support and Michael D. Krom acknowledges support from the Leverhulme Foundation with grant RPG-406 and LGB from the UK Natural Environment Research Council grant number NE/J008745/1. Jon R. Hawkings, Martyn Tranter, and Jemma Wadham were funded by the NERC DELVE project (NERC grant NE/I008845/1 and the associated NERC $\mathrm{PhD}$ studentship). The authors are grateful to Lyndsay Hilton from the Thomas Hardye School, Dorset, who provided Antarctic glacial ice samples collected during participation on a Fuchs Foundation charity expedition. The Patagonian dust samples were supplied by S. Clerici. We are grateful to Mark Hopwood for drawing our attention to iceberg losses in Greenlandic fjords.

Edited by: C. P. Slomp

\section{References}

Albani, S., Mahowald, N. M., Perry, A. T., Scanza, R. A., Zender, C. S., Heavens, N. G., Maggi, V., Kok, J. F., and Otto-Bliesner, B. L.; Improved dust representation in the Community Atmosphere Model, J. Adv. Model. Earth Syst., 6, 541-570, 2014.

Baker, A. R. and Croot, P. L.; Atmospheric and marine controls on aerosol solubility in seawater, Mar. Chem., 120, 4-13, 2010.

Baker, A. R., Jickells, T. D., Witt, M., and Linge, K. L.; Trends in the solubility of iron, aluminium, manganese and phosphorus in aerosol collected over the Atlantic Ocean, Mar. Chem., 98, 4358, 2006.

Bamber, J., van den Broeke, M., Ettema, J., Lenarts, J., and Rignot, E.; Recent large increases in freshwater fluxes from Greenland into the North Atlantic, Geophys. Res. Lett., 39, L19501, doi:10.1029/2012GL052552, 2012.

Barbeau, K., Moffett, J. W., Caron, D. A., Croot, P. L., and Erdner, D. L., Role: of protozoan grazing in relieving iron limitation of phytoplankton, Nature, 380, 61-64, 1996.

Berger, C. J. M., Lippiat, S. M., Lawrence, M. G., and Bruland, K. W.: Application of a chemical leach technique for estimating labile particulate aluminium, iron and manganese in the Columbia River plume and coastal waters off Oregon and Washington, J. Geophys. Res., 113, C00B01, doi:10.1029/2007JC004703, 2008.

Boyd, P. W., Mackie, D. S., and Hunter, K. A.: Aerosol iron deposition to the surface ocean-Modes of iron supply and biological responses, Mar. Chem., 120, 128-143, 2010.

Boyd, P. W., Arrigo, K. R., R., Stzepekand, R., and van Dijken, G. L.: Mapping phytoplankton iron utilization: insights into Southern Ocean supply mechanisms, J. Geophys. Res., 117, C06009, doi:10.1029/2011JC007726, 2012.

Breitbarth, E., Achterberg, E. P., Ardelan, M. V., Baker, A. R., Bucciarelli, E., Chever, F., Croot, P. L., Duggen, S., Gledhill, M., Hassellöv, M., Hassler, C., Hoffmann, L. J., Hunter, K. A., Hutchins, D. A., Ingri, J., Jickells, T., Lohan, M. C., Nielsdóttir, M. C., Sarthou, G., Schoemann, V., Trapp, J. M., Turner, D.
R., and Ye, Y.: Iron biogeochemistry across marine systems progress from the past decade, Biogeosciences, 7, 1075-1097, doi:10.5194/bg-7-1075-2010, 2010.

Brinza, L.: Interactions of molybdenum and vanadium and iron nanoparticles, $\mathrm{PhD}$, Department of Earth and Environment, University of Leeds, 2010.

Chen, Y. and Siefert, R. L.: Determination of different types of labile atmospheric iron over remote oceans, J. Geophys. Res., 108, D244774, doi:10.29/2003JD003515, 2003.

Chewings, J. M., Atkins, C. B. Dunbar, G. B., and Golledge, N. R.: Aeolian sediment transport and deposition in a modern highlatitude glacial marine environment, Sedimentology, 61, 15351557, 2014.

Conway, T. M. and John, S. G.: Quantification of dissolved iron sources to the North Atlantic, Nature, 511, 212-215, 2014.

Conway, T. M., Wolf, E. W., Rothlisberger, R., Mulvaney, R., and Elderfield, H. E.: Constraints on soluble aerosol iron flux to the southern Ocean during the Last Glacial Maximum, Nat. Commun., 6, 7850, doi:10.1038/ncomms8850, 2015.

Dale, A. W., Nickelsen, L., Scholz, F., Hensen, C., Oschlies, A., and Wallman, K.: A revised global estimate of dissolved iron fluxes from marine sediments, Global Biogeochem. Cy., 29, 691-707, doi:10.1002/2014GB005017, 2015.

Death, R., Wadham, J. L., Monteiro, F., Le Brocq, A. M., Tranter, M., Ridgwell, A., Dutkiewicz, S., and Raiswell, R.: Antarctic ice sheet fertilises the Southern Ocean, Biogeosciences, 11, 26352643, doi:10.5194/bg-11-2635-2014, 2014.

Depoorter, M. A., Bamber, G. L., Griggs, J. A., Lenaerts, T. M., Ligtenberg, S. R. M., van den Broeke, M. R., and Moholdt, G.: Calving fluxes and basal melt rates of Antarctic ice shelves, Nature, 502, 89-92, 2013.

Diemand, D.: Icebergs, Encyclopaedia of Ocean Sciences, edited by: Steale, J. H., Turekian, K. K., and Thorpe, S. A., Academic Press, 181-190, 2008.

Dowdeswell, J. A. and Dowdeswell, E. K.; Debris in icebergs and rates of glaci-marine sedimentation-observations from Spitzbergen and a simple model, J. Geol., 97, 221-231, 1989.

Duprat, L. P. A. M., Bigg, G. R., and Wilton, D. J.: Giant icebergs significantly enhance the marine productivity of the Southern Ocean, Nat. Geosci, 9, 219-221, 2016.

Dyurgerov, M., Bring, A., and Destouni, G.: Integrated assessment of changes in freshwater inflow to the Arctic Ocean, J. Geophys. Res., 115, D12116 doi:10.1029/2009JD013060, 2010.

Edwards, R. and Sedwick, P.: Iron in East Antarctic snow: Implications for atmospheric iron deposition and algal production in Antarctic waters, Geophys. Res. Lett., 28, 3907-3910, 2001.

Enderlin, E. M., Howat, I. M., Jeong, S., Noh, M.-J., van Angelen, J. H., and van den Broeke, M. R.: An improved mass budget for the Greenland ice sheet, Geophys. Res. Lett., 41, 866-872, 2014.

Gaiero, D. M., Brunet, F., Probst, J.-L., and Depetris, P. J.: A uniform isotopic and chemical signature of dust exported from Patagonia: Rock sources and occurrence in southern environments, Chem. Geol., 238, 107-129, 2007.

Gao, Y., Fan, S.-M., and Sarmiento, J. L.: Atmospheric iron input to the ocean through precipitation scavenging: A modeling perspective and its implication for natural iron fertilization in the ocean, J. Geophys. Res., 108, D74221, doi:1029/2002JD002420, 2003.

Hassler, C. S., Alasonati, E., Mancuso Nichols, C. A., and Slaveykova, V. I.: Exopolysaccharides produced by bacteria iso- 
lated from pelagic southern Ocean-Role in Fe binding, chemical reactivity and bioavailability, Mar. Chem., 123, 88-98, 2011.

Hassler, C. S., Norman, L., Mancuso Nichols, C. A., Clementson, L. A., Robinson, C., Schoemann,V., Watson, R. J., and Doblin, M. A.: Iron associated with exopolymeric substances is highly bioavailable to oceanic phytoplankton, Mar. Chem., 173, 136$147,2015$.

Hawkings, J. R., Wadham, J. L., M. Tranter, M., Raiswell, R., Benning, L. G., Statham, P. J., Tedstone, A., Nienow, P., Lee, K., and J. Telling, J.: Ice sheets as a significant source of highly reactive nanoparticulate iron to the oceans, Nat. Commun., 5, 3929, doi:10.1038/ncomms4929, 2014.

Heimburger, A., Losno, R., and Triquet, S.: Solubility of iron and other trace elements in rainwater collected on the Kerguelen Islands (South Indian Ocean), Biogeosciences, 10, 6617-6628, doi:10.5194/bg-10-6617-2013, 2013.

Hiemstra, T.: Surface and mineral structure of ferrihydrite, Geochim. Cosmochim. Ac., 105, 316-325, 2013.

Hopwood, M. J., Statham, P. J., Tranter, M., and Wadham, J. L.: Glacial flours as a potential source of $\mathrm{Fe}(\mathrm{II})$ and $\mathrm{Fe}(\mathrm{III})$ to polar waters, Biogeochemistry, 118, 443-452, doi:10.1007/s10533013-9945-y, 2014.

Hopwood, M. J., Bacon, S., Arendt, K., Connelly, D. P., and Statham, P. J.: Glacial meltwater from Greenland is not likely to be an important source of Fe to the North Atlantic, Biogeochemistry, 124, 1-11, 2015.

Hopwood, M. J., Connelly, D. P., Arendt, K. E., Jull-Petersen, T., Stinchcombe, M., Meire, L., Esposito, M., and Krishna, R.: Seasonal changes in $\mathrm{Fe}$ along a glaciated fjord Greenlandic fjord, Front. Earth Sci., 4, 15, doi:10.3389/feart.2016.00015, 2016.

Hyacinthe, C. and Van Cappellen, P.: An authigenic iron phosphate phase in estuarine sediments: composition, formation and chemical reactivity, Mar. Chem., 91, 227-251, 2004.

IPCC: Long-term Climate Change: Projections, Commitments and Irreversibility, 5th Assessment Report, Chapter 12, 2013.

Ito, A.: Atmospheric processing of combustion aerosols as a source of bioavailable iron, Environ. Sci. Tech. Lett., 2, 70-75, 2015.

Jahnke, R. A.: Global synthesis, in: Carbon and Nutrient Fluxes in Continental Margins, Global Change-The IGBP Series, edited by: Liu K.-K., Atkinson, L. Quinones, R., and Talaue-McManus, L., Chap. 16, Springer-Verlag, Berlin, 2010.

Jeong, D., Kim, K., and Choi, W.: Accelerated dissolution of iron oxides in ice, Atmos. Chem. Phys., 12, 11125-11133, doi:10.5194/acp-12-11125-2012, 2012.

Jeong, D., Kim, K., Min, D. W., and Choi, W.: Freezing-enhanced dissolution of iron oxides, Effects of inorganic acid anions, Env. Sci. Tech., 40, 12816-12822, 2015.

Jickells, T. D. and Spokes, L. J.: Atmospheric inputs to the ocean, in: The Biogeochemistry of Iron in Seawater, edited by: Turner, D. R. and Hunter, K. A., Wiley, New York, 123-251, 2001.

Jickells, T. D., An, Z. S., Anderson, K. K., Baker, A. R., Bergametti, G., Brooks, N., Cao, J. J., Boyd, P. W., Duce, R. A., Hunter, K. A., Kawaahata, H., Kubilay, N., LaRoche, J., J., Liss, P. S., Mahowald, N., Prospero, J. M., Ridgewell, A., Tegen, I., and Torres, R.: Global iron connections between desert dust, ocean biogeochemistry, and climate, Science, 308, 67-73, 2005.

Kim, K., Choi, W., Hoffmann, M. R., Yoon, H. I., and Park, B. K.: Photoreductive dissolution of iron oxides trapped in ice and its environmental implications, Env. Sci., Tech., 44, 4142-4148, 2010.

Kostka, J. E. and Luther III, G. W.: Partitioning and speciation of solid phase iron in saltmarsh sediments, Geochim. Cosmochim. Ac., 58, 1701-1710, 1994.

Kuma, K. and Matsunaga, K.: Availability of colloidal ferric oxides to coastal marine phytoplankton, Mar. Biol., 122, 1-11, 1995.

Lafon, S., Rajot, J.-L., Alfaro, S. C., and Gaudichet, S.: Quantification of iron oxides in desert aerosol, Atmos. Env., 38, 1211-1218, 2004.

Lafon, S., Sokolik, I. N., Rajot, J.-L., Caquineau, S., and Gaudichet, S.: Characterization of iron oxides in mineral dust aerosols; implications for light absorption, J. Geophys. Res., 111, D21207, doi:10.1029/2005/JD007016, 2006.

Lancelot, C., de Montety, A., Goosse, H., Becquevort, S., Schoemann, V., Pasquer, B., and Vancoppenolle, M.: Spatial distribution of the iron supply to phytoplankton in the Southern Ocean: a model study, Biogeosciences, 6, 2861-2878, doi:10.5194/bg-62861-2009, 2009.

Lannuzel, D., Schoemann, V., de Jong, J., Tison, J.-L., and Chou, L.: Distribution and biogeochemical behavior of iron in the East Antarctic sea ice, Mar. Chem., 106, 18-32, 2007.

Lannuzel, D., Schoemann, V., de Jong, J., Chou, L., Delille, B., Becquevort, S., and Tison, J.-L.: Iron study in during a time series in the western Weddell Sea pack ice, Mar. Chem., 108, 85-95, 2008.

Lannuzel, D., van der Merwe, P. C., Townsend, A. T., and Bowie, A. R.: Size fractionation of iron, manganese and aluminium in Antarctic fast ice reveals a lithogenic origin and low iron solubility, Mar. Chem., 161, 47-56, 2014.

Li, F., Ginoux, P., and Ramaswamy, V.: Distribution, transport, and deposition of mineral dust in the Southern Ocean and Antarctica: contribution of major sources, J. Geophys. Res., 113, D10207, doi:10.1029/2007JD009190, 2008.

Lin, H. and Twining, B. S.: Chemical speciation of iron in Antarctic waters surrounding free-drifting icebergs, Mar. Chem., 128/129, 81-91, 2012.

Luo, C., Mahowald, N., Bond, T., Chuang, P. Y., Artaxo, P., Siefert, R., Chen, Y., and Schauer, J.: Combustion iron distribution and deposition, Global Biogeochem.Cy., 22, GB1012, doi:10.1029/2007GB002964, 2008.

Lutz, A. M., Arieso, S. E., Villar, J., and Benning, L. G.: Variation in algal communities cause darkening of a Greenland glacier, F.E.M.S., Microbial Ecol., 89, 402-414, 2014.

Mackenzie, F. T. and Andersson, A. J.: The marine carbon cycle and ocean acidification during Phanerozoic time, Geochem. Perspect., 2, 1-227, 2013.

Mahowald, N., Baker, A., Bergametti, G., Brooks, N., Duce, R., Jickells, T. D., Kubilay, N., Prospero, J., and Tegen, I.: The atmospheric global dust cycle and iron inputs into the ocean, J. Geophys. Res., 111, D05303, doi:10.1029/2005JD006459, 2005.

Mahowald, N., Albani, S., Engelstaeder, S., Winckler, G., and Goman, M.: Model insight into glacial-interglacial dust records, Quat. Sci. Rev., 30, 832-854, 2011.

Meguro, H., Toba, Y., Murakami, H., and Kimura, N.: Simultaneous remote sensing of chlorophyll, sea ice and sea surface temperature in the Antarctic waters with special reference to the primary production from ice algae, Adv. Space Res., 33, 116-1172, 2004. 
Moore, C. M., Mills, M. M., Arrigo, K. R., Berman-Frank, I., Boyd, P. W., Galbraith, E. D., Geidler, R. J., Guieu, C., Jaccard, S. L., Jickells, T. D., La Roche, J., Lenton, T. M., Mahowald, N. M., Marnon, E., Marinov, I., Moore, J. K., Nakatsuka, T., Oschlies, A., Saito, M. A., Thingstad, T. F., Tsuda, A., and Ulloa, O.: Processes and patterns of oceanic nutrient limitation, Nat. Geosci., 6, 701-710, 2013.

Moore, J. K., Abbott, M. R., and Richman, J. G.: Location and dynamics of the Antarctic Polar Front from satellite sea surface temperature data, J. Geophys. Res., 104, 3059-3073, 1999.

Nielsdottir, M. C., Moore, C. M., Sanders, R., Hinz, D. J., and Achterberg, E. P.: Iron limitation of the postbloom phytoplankton communities in the Iceland Basin, Global Biogeochem. Cy., 23, GB3001, doi:10.1029/2008GB003410, 2009.

Nodwell, L. M. and Price, N. M.: Direct use of inorganic colloidal iron by marine thixotrophic phytoplankton, Limnol. Oceanogr., 46, 765-777, 2001.

Pabi, S., van Dijken, G. L., and Arrigo, K. R.: Primary production in the Arctic Ocean, J. Geophys. Res., 113, C08005, doi.org/10.1029/2007JC004578, 2008.

Popova, E. E., Yool, A., Coward, A. C., Aksenov, Y. K., Alderson, S. G., de Cuevas, B. A., and Anderson, T. R.: Control of primary production in the Arctic by nutrients and light: insights from a high resolution ocean general circulation model, Biogeosciences, 7, 3569-3591, doi:10.5194/bg-7-3569-2010, 2010.

Poulton, S. W. and Canfield, D. E.: Development of a sequential extraction procedure for iron: implications for iron partitioning in continentally-derived particulates, Chem. Geol., 214, 209-221, 2005

Poulton S. W. and Raiswell, R.: The low-temperature geochemical cycle of iron: from continental fluxes to marine sediment deposition, Amer. J. Sci., 302, 774-805, 2002.

Pritchard, H. D., Ligtenberg, S. R. M., Fricker, H. A., Vaughan, D. G., van den Broeke, M. R., and L. Padman, L.: Antarctic icesheet loss driven by basal melting, Nature, 484, 502-505, 2012.

Raiswell, R.: Iceberg-hosted nanoparticulate Fe in the Southern Ocean: Mineralogy, origin, dissolution kinetics and source of bioavailable Fe, Deep-Sea Res. Pt. II, 58, 1364-1375, 2011.

Raiswell, R. and Canfield, D. E.: The iron biogeochemical cycle past and present, Geochem. Perspect., 1, 1-220, 2012.

Raiswell, R., Canfield, D. E., and Berner, R. A.: A comparison of iron extraction methods for the determination of degree of pyritization and recognition of iron-limited pyrite formation, Chem. Geol., 111, 101-111, 1994.

Raiswell R., Tranter, M., Benning, L. G., Siegert, M., Death, R., Huybrechts, R. P., and Payne, T.: Contributions from glacially derived sediment to the global iron oxyhydroxide cycle: implications for iron delivery to the oceans, Geochim. Cosmochim. Ac., 70, 2765-2780, 2006.

Raiswell, R., Benning, L. G., Tranter, M., and Tulaczyk, S.: Bioavailable iron in the Southern Ocean: The significance of the iceberg conveyor belt, Geochem. Trans., 9, 7, doi:10.1186/14674866-9-7, 2008.

Raiswell, R., Vu, H. P., Brinza, L., and Benning, L. G.: The determination of $\mathrm{Fe}$ in ferrihydrite by ascorbic acid extraction: methodology, dissolution kinetics and loss of solubility with age and de-watering, Chem. Geol., 278, 70-79, 2010.
Reyes, I. and Torrent, J.: Citrate-ascorbate as a highly selective extractant for poorly crystalline iron oxides, Soil Sci. Soc. Amer. J., 61, 1647-1654, 1997.

Rich, H. W. and Morel, F. M. M.: Availability of well-defined iron colloids to the marine diatom Thalassiosiraweissflogii, Limnol. Oceanogr., 35, 652-662, 1990.

Rignot, E., Velicogna, I., van den Broeke, M. R., Monoghan, A., and Lenaerts, J.: Acceleration of the contribution of the Greenland and Antarctic ice sheets to sea level rise, Geophys. Res. Lett., 38, L05503, doi:10.1029/2011GL046583, 2011.

Schulz, M., Prospero, J. M., Baker, A. R., Dentener, F., Ickes,L., Liss, P. S., Mahowald, N., Nickovic, S., Garcia-Pando, C. P., Rodriguez, S., Sarin, M., Tegen, I., and Duce, R. A.: Atmospheric transport and deposition of mineral dust to the ocean: Implications for research needs, Env. Sci. Tech., 46, 10390-10404, 2012.

Schwertmann, U., Stanjek, H., and Becher, H.-H.: Long term in vitriol transformation of 2-line ferrihydrite to goethite/hematite at 4, 10, 15 and $25^{\circ} \mathrm{C}$, Clay Miner., 39, 433-438, 2004.

Sedwick, P. N., Sholkovitz, E. R., and Church, T. M.: Impact of anthropogenic combustion emissions on the fractional solubility of aerosol iron: Evidence from the Sargasso Sea, Geochem. Geophys. Geosys., 8, 10, doi:10.1029/2007GC001586, 2007.

Shaked, Y. and Lis, H.: Disassembling iron availability to phytoplankton, Front. Microbiol., 123, 1-26, 2012.

Shaw, T. J., Raiswell, R., Hexel, C. R., Vu, H. P., Moore, W. S., Dudgeon, R., and Smith, K. L.: Input, composition and potential impact of terrigenous material from free-drifting icebergs in the Weddell Sea, Deep-Sea Res. Pt. II, 58, 1376-1383, 2011.

Shi, Z., Krom, M. D., Bonneville, S., Baker, A. R., Jickells, T. D., and Benning, L. G.: Formation of iron nanoparticles and increase in iron reactivity in mineral dust during simulated cloud processing, Env. Sci. Tech., 43, 6592-6596, 2009.

Shi, Z., Krom, M. D., Bonneville, S., Baker, A. R., Bristow, C., Mann, G., Carslaw, K., McQuaid, J. B., Jickells, T., and Benning, L. G.: Influence of chemical weathering and aging of iron oxides on the potential iron solubility of Saharan dust during simulated atmospheric processing, Global Biogeochem. Cy., 25, GB2010, doi:10.1029/2010GB003837, 2011.

Shi, Z., Krom, M. D., Jickells, T. D., Bonneville, S., Carslaw, K. S., Mihalpoulos, N., Baker, A. R., and Benning, L. G.: Impacts on iron solubility in the mineral dust by processes in the source region and the atmosphere: A review, Aeolian. Res., 5, 21-42, 2012.

Shi, Z., Krom, M. D., Bonneville, S., and Benning, L. G.: Atmospheric processing outside clouds increases soluble iron in mineral dust, Env. Sci. Tech., 49, 1472-1477, 2015.

Silva, T. A. M., Bigg, G. R., and Nicholls, K. W.: Contribution of giant icebergs to the Southern Ocean freshwater flux, J. Geophys. Res., 111, C03004, doi:10.29/2004JC002843, 2006.

Smith, K. L., Robison, B. H., Helly, J. J., Kaufmann, R. S., Ruhl, H. A., Shaw, T. J., Twining, B. S., and Vernat, M.: Free-drifting icebergs: Hot spots of chemical and biological enrichment in the Weddell Sea, Science, 317, 478-483, 2007.

Smith, K. L., Sherman, A. D., Shaw, T. J., and Springall, J.: Icebergs as unique Lagrangrian ecosystems in polar seas, Ann. Rev. Mar. Sci., 5, 269-287, 2013.

Stookey, L. L.: Ferrozine- A new spectrophotometric reagent for iron, Anal. Chem., 42, 779-781, 1970. 
Straneo, F. and Cenedese, C.: The dynamics of Greenland's glacial fjords and their role in climate, Ann. Rev. Mar. Sci., 7, 89-112, 2015.

Sugie, K., Nishioka, J., Kuma, K., Volkov, Y. N., and Nataksuka, T.: Availability of particulate Fe to phytoplankton in the Sea of Okhotsk, Mar. Chem., 152, 20-31, 2013.

Sutherland, D. A., Roth, G. E., Hamilton, G. S., Mernild, S. H., Stearns, L. A., and Straneo, F.: Quantifying flow regimes in a glacial fjord using iceberg drifters, Geophys. Res. Lett., 41, 8411-8420, 2014.

Tagliabue, A. and Völker, C.: Towards accounting for dissolved iron speciation in global ocean models, Biogeosciences, 8, 30253039, doi:10.5194/bg-8-3025-2011, 2011.

Tagliabue, A., Bopp,L., and Aumont, O.: Evaluating the importance of atmospheric and sedimentary iron sources to Southern Ocean biogeochemistry, Geophys. Res. Lett., 36, L13601, doi:10.1029/2009GL038914, 2009.

Tagliabue, A., Bopp, L., Dupay, J.-C., Bowie, A.R., Chever, F., Jean-Bapiste, P., Bucciarelli, E., Lannuzel, D., Remenyi, T., Sarthou, G., Aumont, O., Gehlen, M., and Jeandel, C.: Hydrothermal contribution to the oceanic inventory, Nat. Geosci., 3, 252-256, 2010.

Tagliabue, A., Aumont, O., Death, R., Dunne, J. P., Dutkiewicz, S., Galbraith, E., Misumi, K., Moore, J. K., Ridgewell, A., Sherman, E., Stock, C., Vichi, M., Volker, C., and Yool, A.: How well do global ocean biogeochemistry models simulate dissolved iron distributions?, Global Biogeochem. Cy., 30, doi:10.1002/2015GB005289, 2016.

Tranter, M. and Jones, H. G.: The chemistry of snow: processes and nutrient recycling, in: The Ecology of Snow, edited by: Jones, $\mathrm{H}$. G., Pomeroy, J. W., Walker, D. A., and Hoham, R., Cambridge University Press, 127-167, 2001.
Vancoppenolle, M., Meiners, K. M., Michel, C., Bopp, L., Brabant, F., Carnat, G., Delille, B., Lannuzel, D., Madec, G., Moreau, S., Tison, J.-L., and van der Merwe, P.: Role of sea ice in global biogeochemical cycles: Emerging views and challenges, Quaternary Sci. Rev., 79, 207-230, 2013.

Van Wychen, W., Burgess, D. O., Gray, L., Copland, L., Sharp, M., Dowdeswell, J. A., and Bentham, T. J.: Glacier velocities and dynamic ice discharge from the Queen Elizabeth Islands, Nunavut, Canada, Geophys. Res. Lett., 41, 484-490, 2014.

Vaughan, D. G.: Recent trends in melting conditions on the Antarctic Peninsula and their implications for ice-sheet mass balance and sea level, Arct. Antarct. Alp. Res., 38, 147-152, 2006.

Wadley, M. R. Jickells, T. D., and Heywood, K. J.: The role of iron sources and transport for Southern Ocean productivity, Deep-Sea Res. Pt. I, 87, 82-94, 2014.

Wang, S., Bailey, D., Lindsay, K., Moore, J. K., and Holland, M.: Impact of sea ice on the marine iron cycle and phytoplankton productivity, Biogeosciences, 11, 4713-4731, doi:10.5194/bg11-4713-2014, 2014.

Wells, M. L., Zorkin, N. G., and Lewis, A. G.: The role of colloid chemistry in providing a source of iron to phytoplankton, J. Mar. Res., 41, 731-746, 1983.

Winton, V. H. L., Dunbar, G. B., Berteler, N. A. N., Millet, M.-A., Delmonte, B., Atkins, C. B., Chewings J. M., and Andersson, P.: The contribution of aeolian sand and dust to iron fertilization of phytoplankton blooms in the southwestern Ross Sea, Antarctica, Global Biogeochem. Cy., 28, 423-436, 2014.

Winton, V. H. L., Bowie, A. R., Edwards, R., Keywood, M., Townsend, A. T., van der Merwe, P., and Bollhofer, A.: Fractional solubility of atmospheric iron inputs to the Southern Ocean, Mar. Chem., 177, 20-32, 2015. 